\title{
Criterion Indicators in Environment Quality Assessment
}

\author{
G.A.Berdesheva \\ Academic Department on Common hygiene and ecology of the West-Kazakhstan, Marat Ospanov State Medical University \\ gulshok85@mail.ru \\ Zh.A.Moldashev
}

Academic Department on Common hygiene and ecology of the West-Kazakhstan, Marat Ospanov State Medical University gulshok85@mail.ru

\section{G.U.Koishygulova}

Academic Department on Common hygiene and ecology of the West-Kazakhstan, Marat Ospanov State Medical University gulshok85@mail.ru

\section{Zh.B.Besimbayeva}

Academic Department on Common hygiene and ecology of the West-Kazakhstan, Marat Ospanov State Medical University gulshok85@mail.ru

B.B.Srazh

Academic Department on Common hygiene and ecology of the West-Kazakhstan, Marat Ospanov State Medical University gulshok85@mail.ru

Ye.Izenbayev

Academic Department on Common hygiene and ecology of the West-Kazakhstan, Marat Ospanov State Medical University gulshok85@mail.ru

\section{A.S.Zhubaniyazova}

Academic Department on Common hygiene and ecology of the West-Kazakhstan, Marat Ospanov State Medical University gulshok85@mail.ru

\section{Doi:10.5901/mjss.2014.v5n23p2638}

\section{Abstract}

Purpose of the research: carrying out of medical and ecological dividing into districts of the main industrial centers of Aktobe oblast (Aktobe, Alga and Khromtau) as leading pollutants of the environment (air, potable and surface water, soil) at this territory and assessment of their health effects to this region's children. Materials and methods. The followings are studied in a research: climatic conditions (temperature, humidity, atmosphere pressure, air velocity), potable and surface water, soil and snow cover, atmospheric precipitation, incidence by appealability and mortality rate of the children. Used methods: epidemiological, statistical, extracts, questionnaire method, mathematical etc. Results. As a result, the data confirming impact of environment factors on population's health and its mortality. Correlations synergies between diseases incidence and environment quality are determined. Preventive measures, focused on health status of children are developed. Conclusion. Criterion indicators are the main in environment quality assessment and may work as evaluative indicators.

Keywords: environment, disease incidence, mortality rate, atmosphere, potable water, surface water, chemical elements, emissions of industrial companies, correlation, regression, interrelation, ecology, pollution.

\section{Introduction}

Health status of the population is an important indicator of social development; reflection of social-economical and hygienic well-being of the country, as well as it is powerful economical, labor, defensive and cultural potential of the 
society.

Health status of the population is described by a system of statistical indicators, defining features of population reproduction (medical and demographical features), reserve of physical forces or legal capacity (indicators of population's physical development), features of population's adaption to environment conditions (diseases incidence of population).

Such working determination, measured by particular medical and demographical indicators according to the level (quality) of population's health cannot fully describe the public health. The notion-public health is something more important, both in general purpose and in social terms; it may be considered as one of conditions (features, quality) of that social organism, such as population, living in a certain territory.

Meanwhile, health of a person shall be considered as dynamic condition (process) of keeping and development of its biological, physiological and psychic functions, optimal working capacity and social activity at maximum long-term and active life.

Insomuch as the health status is a dynamic process, it may be improved or decreased depending on the environment.

Present knowledge of science and practice testify that there are separate places (regions) of increased risk (probability) of becoming ill by certain forms of pathology. It appears that the risk may be stable, existing for a long time or temporary, occurring in case of social* or natural environmental disturbances. Today the question of necessity of typing of social and ecological zones, specific for expansion of various diseases of a human. Therefore, ecological approach for evaluation of human's health expects that, a human being the part of nature may live in a certain environment, limited by its own parameters. In addition to the common indicators for health describing at studying of the impact of environment pollutions on it, indicators allowing assessing functional condition of organism by various physiological and bio-chemical changes shall be valuable. These changes do not yet entail the disease, but reduce adaptation possibilities of organism and united to the notion of premorbid conditions.

Recording of methodic features and arrangement of information collection are obligatory condition during assessment of statistical indicators of population diseases incidence. The main source of information is the reporting medical documentation, medical examinations of population, public inquiry. Methods of direct supervision over contingent shall be also used.Detailed complex medical examinations of population by team of medical specialists shall be considered as the first stage in regards to methodical methods during assessment of information fullness, the second is involving of specialists upon indicators, the third- materials on appealability of population for medical treatment within various terms and the last one is materials on appealability of population for medical treatment per one year>

Based on results of researches, health status, diseases incidence and mortality of children of specified regions are retrospectively studied. The scientists consider that expansion of disease incidence among large population contingents is conditioned by impact of chemical substances at the current time; however, this problem requires the further advanced examination.

Analysis of obtained literary data shall give a reason to consider the atmospheric pollution as one of the most important risk factors for the population health among the total amount of environment factors.

Based on data of literature the chemical environment pollution, artificially created by chemical substances has a large hazard for the population health at the present time. Modern industry produces for about 70 thousands of synthetic materials, toxic properties are revealed from 1500 of them. Half of them have carcinogenic properties, which substantially change the course and result of acute and chronic diseases. Another part of them interrupts pregnancy process and prenatal fetal development as well as has direct and side effect on a human's health.

Based on literature data, it is also known that use of chemical means in agriculture have negative impact on health of population. Separate consequences as oncoma of various localization, neuropathy, pregnancy failure etc. are defined. Relation between the diseases incidence, profession, age of employees and mentioned factors (pesticides, herbicides etc.) is determined. The risk of occurrence of leucosis, lymphs and cancer of stomach and prostate gland are being substantially increased under their impact. There is ahypothesis of complex impact of pesticides, chemical carcinogens and viruses.

Permanent pollution of potable water and surface water by various toxic substances of industrial and household wastes also has severe consequences for the health of the population and succeeding generation. Studying of influence of the pollution on living organism has revealed the close relationship between levels of environment pollution and mortality indicators. High level of urbanization, increasing the frequency of stress situations, pollution of water and air has an impact on growth of mortality because of cardiovascular diseases for $50 \%$ and cancer for $20-25 \%$.

It is also required to take into consideration that impact of external factors on organism condition, including the children shall not be limited by time of influence, but it shall affect later in significant level on growth and its development, formation of adult's health. 
Taking into account that human organism is under permanent interrelation with environment from the birth date, it is required to create the most favorable conditions for their equation, which shall be reached by two ways: impact on environment (its hygienic rating) and human organism (training since childhood, temper development etc.).

Physical development has a certain value as the main factor in assessment of children's health. The level of physical training is also considered as the important criteria of organism reaction on change of hygienic characteristics of environment, reflection of social specificities, both micro-collective and society's conditions and the way of life.

Thus, development of living organism is closely related with certain conditions of the environment, which requires studying of impact of various environment factors on the population's health status and determination of priority indicators of environment quality in order to develop the preventive and healthful measures in the field of the population's health protection.

\section{Materials and Methods}

Methodical recommendations on unification of methods of examination and the population's health assessment due to the environment factors (1987), as well as methodical recommendations- Forecast of population's diseases incidence due to the change of environment factors of a big city, prepared jointly with the Scientific-Research Institute named after A.N. Sysin (Moscow'., 1987) are used during performance of the main volume of planned researches.

Researches are performed stepwise, retrospectively, based on real conditions of the region:

1. Selection and analysis of research regions (Aktobe, Alga, Khromtau).

2. Studying of environment items conditions (Atmosphere air, potable water and surface water, climatic and geographical indicators etc.), brief characteristics of the main environment pollutants, diseases incidence of children based on visits to medical preventive institutions and reporting data of healthcare organizations, social and economic characteristics of the region.

3. Finding out of interrelation between indicators, describing the environment condition of examined cities and health status of children, causes of diseases. Determination of priority indicators of the environment and health condition with the purposes of interrelation assessment.

We have selected and analyzed the data on condition of environment items for the last six years.

Retrospective and meteorological factors are examined on the basis data of hydrometeorology service.

Assessment of potential hazard of atmosphere polluting (PAP) was carried out by the method of E.Yu.Bezuglova (1983), based on data of long-term frequency of ground inversions and wind speed.

Hygienic assessment of self-purification capacity of atmosphere (SCA) was carried out by the method of V.V.Kryuchkov (1979).

Gross emissions to the region's atmosphere are analyzed based on reporting data of industrial companies on acting information systems 2 TP Air.

Atmosphere air pollution was examined at all three regions. Content of sulphur, sulphurated hydrogen, nitrogen dioxide, dust, chrome was examined in the atmosphere air. Researches are performed retrospectively, including all seasons of the year.

Objects of research, indicators, volume and methods of the research are submitted in the table No.1.

\section{Table No.1}

\begin{tabular}{|c|c|c|c|c|}
\hline No. & Object of research & Indicators under studying & Selection quantity & Methods of research \\
\hline 1 & Atmosphereair & $\mathrm{SO}_{2}, \mathrm{H}_{2} \mathrm{~S}, \mathrm{NO}_{2}$, carbohydratesCr+3, $\mathrm{Cr}^{+6}$, dust, formaldehyde & 700 & Chromatography \\
\hline 2 & Water & $\begin{array}{l}\mathrm{BOD}_{5} \text {, hardness, sulphites, chlorides, } \mathrm{Ca}, \mathrm{B}, \mathrm{F}, \text { nitrites, } \\
\text { nitrates, phosphor, phenols, Fe, } \mathrm{C}^{+6}, \mathrm{Mg}, \mathrm{Mo}, \mathrm{Zn}, \mathrm{Co}, \mathrm{As} \text {, } \\
\mathrm{Hg} \text {, Synthetic Surfactants, oil products, iodine }\end{array}$ & 450 & $\begin{array}{c}\text { Organoleptics. } \\
\text { Physicalandchemical }\end{array}$ \\
\hline 3 & Soil & $\mathrm{Pb}, \mathrm{Zn}, \mathrm{Cи}, \mathrm{W}$ i, Hg, Ag, P, U & 174 & Spectral \\
\hline 4 & Appealability sheet & Diseases incidence & 1350 & $\begin{array}{c}\text { Selection. Statistical } \\
\text { processing }\end{array}$ \\
\hline 5 & Total & & 2674 & \\
\hline
\end{tabular}

Determination of sulphur dioxide is based on its absorption from the air by formaldehyde solution with formation of hydroxymethanesulfoacids. Hydroxymethanesulfoacid will decompose for formaldehyde and $\mathrm{SO}_{2}$ during adding of sodium hydroxide. These substances shall form combination during reaction with pararosaniline, based on which color intensity 
the content of sulphur dioxide shall be defined by photometric method.

$\mathrm{H} 2 \mathrm{~S}$ content is based on its absorption from the air by solution of cadmium complex with triethanolamine and its photometric determination by methylene-blue.

Determination of nitrogen dioxide is based on its capture from the air by iodine of potassium. Formed nitrite ion shall be determined by photometric method.

Dustis determined by weight method by air blowing via the FPAfilter.

Chrome determination was carried out by spectral method of analysis, which is based on excitation of atoms of chrome in alternating-current arc and photographing of spectrum.

Investigation was carried out on open and underground water resources. The main water sources are llek and Kargala rivers. Both the water of open and underground water sources were researched for containing of sulphates, general hardness, nitrites, nitrates, phenol, chrome and fluor. Potable water was researched for its compliance with SanPin 3.01.067-97 RK, as well as for content of chrome, nutramin, ferrum, fluor, iodine, chlorides, sulphates.

The followings were found out in the soil: lead, zinc, copper, nickel, mercury, arsenium, phosphor, manganese. Summary indicator of the soil pollution was defined by amount of coefficients of substances concentration on excess of maximum permissible concentrations (concentration ratioto MPC- with MPC), which has allowed to carry out dividing into districts and separation of priority indicators.

Investigation of general diseases incidence of children is based on the following:

- materials of children's medical preventive institutions on disease incidence based on appealability,

- statistical materials of children's hospitals,

- selective performance of medical examinations.

Children were selected in order to determine the impact of environment factors on population's health status. It is conditioned that children are not under the influence of production factors and do not have bad habits, i.e. children's health status may be considered as one of Criterion indicators of the environment impact.

Drawing of samples from the environment items was carried out jointly with specialists of Sanitary \& Epidemiological Station where their analyses were performed. Retrospective data on pollution condition of environment items are gathered and analyzed based on materials of the Hydrometeorologyservice, Sanitary \& Epidemiological Station bodies and Aktobe oblast's territorial administration of the environment protection. The part of data was selected independently.

Due to the fact that the work was planned for 3 years, but work has performed in 3 months, results are retrospective and prepared on the basis of data, analyzed for the last 6 years.

We have used mathematical and statistical models for numeral variables with the purpose of impact assessment of the environment condition for diseases incidence of children.

Multiple correlation-regression analysis was used as device of mathematical analysis with the purpose of carrying out of cause-and-effect relation and examination of impact of ecological factors on the level and structure of disease incidence of the region's children.

We have analyzed the retrospective data of chemical analyses of number of environment protection institutions for ecological and hygienic assessment of environment items.

All the listed and used methods have allowed us to carry out medical and ecological dividing into districts of industrial centers of the Aktobe oblast, in particular Aktobe, Khromtau and Alga as well as finding out of priority environment factors, having impact on population and especially children's health.

\section{Results}

Investigation of certain components of region's climate has showed that

1. Average annual air temperature is $+3,6^{\circ} \mathrm{C}$, average monthly minimum (January) $-15^{\circ} \mathrm{C}$, average monthly $\operatorname{maximum}\left(\right.$ July) $+22^{\circ} \mathrm{P}$.

2. Prevailing wind direction by the west rhumb is equal to $15 \%$, upon the North- East, East and North-West about14 \%, upon the North-West - $13 \%$. Other rhumbs from 8 to $12 \%$. Average annual wind speed is equal to $4,7 \mathrm{~m} / \mathrm{sec}$, minimum- 1, $2 \mathrm{~m} / \mathrm{sec}$, maximum $-18 \mathrm{mlsec}$. Number of no wind conditions per year on average about 300. *

3. Average annual barometric pressure is $743 \mathrm{~mm}$. mercury of column, minimum - $736 \mathrm{~mm}$. mercury of column, maximum- $749 \mathrm{~mm}$. mercury of column.

4. Average annual relative humidity of the air is $69 \%$, average monthly - $53-81 \%$, minimum - $53-59 \%$, maximum- 60 - $81 \%$. 
5. Precipitations for years on average $275 \mathrm{~mm}$, their maximum quantity- $387 \mathrm{~mm}$, minimum - $102 \mathrm{~mm}$. Moreover, maximum quantity of precipitations during warm season $-39 \%$ in summer.

6. Sunshine reaches 2223 hours per year (based on data of many years). Their largest numbers are determined since May till September (from 215 to 319 hours), the least on January, November and December (from 47 to 73 hours).

Characteristics of soil pollution at the territory of Aktobe, Alga and Khromtau are as follows:

Lead content, on average is equal to $31 \mathrm{mg} / \mathrm{kg}$ in Aktobe city.

Therefore, ecological condition upon lead in Aktobe shall be considered as hazardous. Especially, taking into account expanding car parks, working on liquid fuel (gasoline, diesel fuel etc.). Territories, where the lead concentrate is more than $60 \mathrm{mg} / \mathrm{kg}$ are considered as zones of critical ecological condition. Approximately all the streets with highdensity traffic and lead concentration for more than $100 \mathrm{mg} / \mathrm{kg}$ - ecological disaster zone, i.e. places of complicated transport junctions, crossings with intense traffic, vehicle lifting on overpass bridges- bridges via the railway and area of the airport. Maximum concentration of lead till $50 \mathrm{mg} / \mathrm{kg}$ or parameters of ecology pollution is observed on the north part of Moscow district.

Based on average content of zinc all the territory may be considered as zone of hazardous ecology situation.

Based on average content of copper, all the examined territory is under ecological hazardous situation.

Standard concentrations of nickel within the urban area are equal to $60-80 \mathrm{mg} / \mathrm{kg}(2$ parameters of environmental pollution of RK), that is complied with hazardous ecological situation.

All the territory of Aktobe shall be considered as ecological disaster zone based on arsenium concentration.

Antimony, phosphor, vanadiumandmanganese, occurred in samples of specific attention do not have impact, i.e. their content does not exceed the maximum permissible concentrations.

Thus, the main criterion components (indicators) of geological environment of Aktobe city are chrome, lead, zinc and arsenium.

Based on retrospective analysis of soil condition of Alga city the following may be concluded:

1. Region, which is being examined, is composite poly-elemental geochemical field, which fully complies with structure of components of elements- environment pollutants. Based on it, the following assumptions shall be made:

2. The region has zones of conditionally maximum influence with high and contrast-variable contents of the most chemical elements, zones of conditionally enhanced concentrations of the most elements with man-caused impact and zones of conditionally weak man-caused impact, characterized by small concentration of the most components of pollution with forthcoming of some of them to background pollution.

3. Maximum technogenic pollution zone is located at the west part of the city.

4. All the examined territory to the west from south part of industrial site may be related to the ecological disaster zone based on components as lead and zinc- content is more than 3 parameters of environment pollution, copper- content is more than 10 parameters of environment pollution.

Retrospective analysis of the soil of Khromtau city has showed that with respect to parameters of environment pollution of UES $(100 \mathrm{mg} / \mathrm{kg})$, ecology condition of the environment at sites with such chrome concentration- element of $2^{\text {nd }}$ class of hazard shall be considered as catastrophic,and if the chrome content is more than $500 \mathrm{mg} / \mathrm{kg}$ at certain zone, then it is critical.

According to collected quantity of nickel, relative value of parameters of environment pollution- ecology condition of the environment may be recognized as catastrophic.

Having analyzed the obtained data on concentration of moving forms of nickel, ecology condition of characterized territory shall be generally hazardous, and forthcoming to the critical condition at sites of industrial companies.

Therefore, based on majority of the main pollutants, basic part of characterized territory may be related to the zone with hazardous ecological condition of geological environment.

Assessment of level of summary Atmosphere air pollution was carried out based on complex P- indicator (coefficient of M.A.Pinigin). Moreover, if any of substances have the level, exceeding the value of indicator for one substance in a complex indicator, in this case pollution assessment shall be carried out upon this substance (Table 2). 
Table 2: Assessment criteria of atmosphere air average annual pollution

\begin{tabular}{|c|c|c|c|}
\hline \multirow{2}{*}{ Indicators } & \multicolumn{2}{|c|}{ Parameters } & Relatively \\
\cline { 2 - 4 } & Ecological disaster & $\begin{array}{c}\text { Emergency } \\
\text { Ecology } \\
\text { Situation }\end{array}$ & $\begin{array}{c}\text { Satisfactory } \\
\text { Situation }\end{array}$ \\
\hline 1 & 2 & 3 & 4 \\
\hline Complex & & & \\
Indicator of & & & 1 \\
average annual & More than 16 & $8-16$ & 2 \\
air & More than32 & $16-32$ & 3 \\
pollution: & More than 48 & $32-48$ & 4 \\
1-substance & More than 64 & $48-64$ & 5 \\
5-4 substances & More than 80 & $64-80$ & \\
\hline
\end{tabular}

Based on obtained results, condition of atmosphere air of Aktobe city may be related to the emergency ecology situation by availability of benzapyrene.

The following indicators shall be considered as criteria of the air environment hazard:

1. Chrome compound (upon $\mathrm{CrO}_{3}$ ).

2. Benzapyrene

3. Sulphurdioxide

4. Nitrogendioxide

5. Inorganicdust.

Based on obtained and retrospective data on quality of atmosphere air of Alga city's region, particularly its north part may be related to the zone of emergency ecology situation (complex indicators of sulphur dioxide,fluorine hydride and dust are almost equal).

However, due to suspension of the work of chemical plant by its type of the basic profile, as well as taking into account its possible conversion, this group of specific ingredients has almost stopped entering into the environment. In connection with this, air basin of Alga city may be characterized as relatively satisfactory at the present time.

Based on data, obtained retrospectively, it may be said that type of air basin pollution of Khromtau city is conditionally shall be characterized as close to emergency ecology situation by hazard criteria of air environment pollution of Khromtau city are still as follows:

1. Chrome compound ( upon $\mathrm{C}_{2} \mathrm{O}_{3}$ )

2. Formaldehyde

3. Nitrogen dioxide.

Condition of pollution of water resources and water supply of population of Aktobe, Alga and Khromtau cities was examined by retrospective analysis of data and water analysis, performed independently. It was determined that potable water at examined industrial centers meet the sanitary and hygienic requirements in general. Thereby, situation with potable water supply of population of Aktobe, Khromtau and Alga cities shall be characterized as relatively satisfactory.

Analysis of the water and these deposits of llek river has testified that examined part of the river may be divided according to the ecology situation as follows:

1. Section of Alga and Aktobe cities -emergency ecology situation.

2. Section of Aktobe city -ecology disaster zone.

3. Lower section of Aktobe city- emergency ecology situation. Priority pollutants of the river-water are boron and chrome. Criterion valuables as follows:

a) phosphor (general)- Water

b) cadmium - Water

c) mercury - Water

d) chrome - Water

e) boron - Water

f) copper - bottom deposits

g) zinc - bottom deposits

Therefore, results of analysis of large number of supervisions over condition of underground water and their pollution shall provide evidences on tension ecological situation near the industrial zone of Aktobe city, 


\section{adjusting to the territory and valley of the llek River.}

The level and structure of disease incidence of children on cities also have their own features.

Table 3: Total disease incidence of children (per one year of life, per 1000 children) on Aktobe city

\begin{tabular}{|c|c|c|c|c|}
\hline \multirow{2}{*}{$\begin{array}{c}\text { Years } \\
\text { of supervision }\end{array}$} & \multicolumn{2}{|c|}{ Zone 1- clean area } & \multicolumn{2}{c|}{ Zone 2 - industrial area } \\
\cline { 2 - 5 } & Total disease incidence & average per year & Total disease incidence & average per year \\
\hline 1 & 1354 & 225,6 & 1862 & 310,3 \\
\hline 2 & 1205,4 & 241,0 & 1612 & 322,4 \\
\hline 3 & 1088,2 & 272,0 & 1545,6 & 386,4 \\
\hline 4 & 1024,6 & 341,5 & 1393,5 & 449,8 \\
\hline 5 & 950,7 & 475,3 & 1370,3 & 685,1 \\
\hline 6 & 722,1 & 722,1 & 1494,4 & 1494,4 \\
\hline
\end{tabular}

Results of researches shows that total disease incidence on zones is various and higher at industrial zone. For example, the first year of life was equal to 1354 at clean and 1862 at polluted zone, third year of life- 1088, 2 and 1545, 6, sixth year of life- 722, 1 and 1494, 4.

There are indicators of children mortality on research areas in the table.

Table 4: Children's mortality indicators by causes (on average per 1000) upon Aktobe city.

\begin{tabular}{|c|c|c|}
\hline Cause of death & Zone 1- clean & Zone 2 - industrial \\
\hline 1 & 2 & 3 \\
\hline Pneumopathy & 3,25 & 4,81 \\
\hline Sepsis & 3,45 & 9,15 \\
\hline Gastrointestinal diseases & 1,56 & 3,91 \\
\hline $\begin{array}{c}\text { Conformational } \\
\text { abnormalities }\end{array}$ & 1,5 & 5,4 \\
\hline Birth injuries & 1,45 & 1,83 \\
\hline
\end{tabular}

Disease incidence of children by upper respiratory airways disasters in Alga, Khromtau cities are in the Table No.5 and No.6.

Table No.5: Disease incidence of children by upper respiratory airway disasters (on average within a year, per 1000) on Alga city

\begin{tabular}{|c|c|c|c|c|}
\hline \multirow{2}{*}{ Age } & \multicolumn{4}{|c|}{ Nosological entity } \\
\cline { 2 - 5 } & Bronchitis & Pharyngitis & Laryngitis & Rhinitis \\
\hline 1 & 2 & 3 & 4 & 5 \\
\hline 1 & 196,9 & 59,3 & 18,3 & 33,2 \\
\hline 2 & 168,2 & 40,6 & 7,8 & 19,2 \\
\hline 3 & 85,7 & 23,9 & 7,7 & 17,0 \\
\hline 4 & 74,5 & 31,6 & 7,5 & 24,8 \\
\hline 5 & 88,7 & 20,2 & 9,9 & 24,7 \\
\hline 6 & 58,7 & 23,2 & 15,3 & 3,5 \\
\hline
\end{tabular}

Table No.6: Disease incidence of children by upper respiratory airway disasters (on average within a year, per 1000) on Khromtau city.

\begin{tabular}{|c|c|c|c|c|}
\hline Age & Bronchitis & Pharyngitis & Laryngitis & Rhinitis \\
\hline 1 & 2 & 3 & 4 & 5 \\
\hline 1 & 281,1 & 33,2 & 5,6 & 35,4 \\
\hline 2 & 179,3 & 32,6 & 3,3 & 39,8 \\
\hline 3 & 158,3 & 31,1 & 7,2 & 49,2 \\
\hline 4 & 160,4 & 23,8 & 7,8 & 50,6 \\
\hline 5 & 146,0 & 28,2 & 7,2 & 54,2 \\
\hline 6 & 196,2 & 20,4 & 2,1 & 39,8 \\
\hline
\end{tabular}


Having analyzed this indicator retrospectively, it is necessary to point out that the main causes of children mortality are also unfavorable factors of the environment, where the child is immediately after the birth.

Having analyzed indicators of children mortality, it may be concluded that pneumopathy is at the first place, sepsis at the second place, conformational abnormalities at the third place.

Results of quality interrelation of the environment and health of children of Aktobe city has showed that environment of Aktobe city has adverse impact on children's health, which shall be confirmed by high correlation coefficients. As it could be expected, primarily, substances of atmosphere are interrelated with respiratory diseases, then with digestive organs and infective diseases. Quality indicators of potable water are interrelated with respiratory diseases and allergic diseases.

Composite indicators of water (according to harmfulness characters) has showed reliable correlation interrelation with allergic and respiratory diseases. Conformational abnormalities and pneumopathy are the most frequent causes of children's death.

According to disease incidence and mortality of children and based on availability of correlation interrelations between the environment factors (atmosphere air, potable water, composite and meteorological indicators) and condition of children's health of Aktobe city, respiration diseases, allergic and digestive organs diseases shall be considered as priority.

The followings may be pointed out from criterion valuable nosological entities, developing under the influence of environment factors: among the diseases- bronchitis, rhinitis, pharyngitis, stomatitis; among death causesconformational abnormalities, pneumopathy, sepsis.

Analysis of performed examinations results upon Alga city shall provide the evidences on availability of correlation between the environment quality, disease incidence and mortality of children of Alga city. Based on dispersion analysis it is possible to state the fact that substances, polluting the environment, which impact on children's health together with meteorological conditions have important role in development of children's disease incidence and mortality.

The followings shall be considered as criterion valuable nosological entities, developing under the influence of environment factors on Alga city:

diseases - bronchitis, pharyngitis, rhinitis.

the main diseases, leading to the death as follows:

pneumopathy, sepsis.

Correlation analysis on Khromtau city has showed that there is correlation between quality of environment, diseases incidence and mortality of children of Khromtau city. The followings shall be considered as criterion valuable nosological entities, developing under the influence of environment factors for Khromtau city: bronchitis, pharyngitis, ehinitis, laryngitis, pneumopathy and sepsis.

\section{Conclusions}

1. Based on obtained data, region's climate may be related to extremely continental. Average annual temperature of the air is favorable. Prevailing winds direction upon the North-East, East and North-West rhumbs. Barometric pressure is within normal limits. Humidity (relative) is about $69-70 \%$, precipitations are mostly during the warm season.

2. According to characteristics of soil pollutants, the main part of characterized territory may be related to the zone of hazardous ecology condition of geological environment. However, obtained data will not allow to carry out ecological dividing into districts in full volume in accordance with available criteria and make it difficult to define the chemical pollution of soil on the population's health.

3. As of condition of the air environment, territory of Aktobe city may be evaluated as relatively ecologically satisfied, Alga city- as relatively satisfied and Khromtau city as zone of emergency ecology situation.

4. Potable water in examined industrial regions is complied with sanitary-hygienic requirements in general. In connection with this, situation with potable water supply of population of Aktobe, Alga and Khromtau cities may be consideredas relatively satisfied.

5. Based on quality of the surface water (llek river), three sections may be pointed out according to ecology situation:

1. Sectionof Alga and Aktobe cities - emergency ecology situation.

2. Section of Aktobe city - ecological disaster zone.

3. Lower section of Aktobe city - emergency ecology situation.

6. Disease incidence and mortality of children shall depend on condition of environment factors, quality of potable 
water and surface water, microclimate indicators.

7. Performed correlation and dispersion analyses have confirmed interrelation and contribution of environment factors to the disease incidence and mortality of children.

\section{Conclusion}

Thereby, performed researches have revealed the complicated ecology situation at the territory of industrial centers of Aktobe oblast. Primarily, it is conditioned by availability of man-made chrome biogeochemical province with kept pollution source of surface and underground water by boron as well as natural biogeochemical province with increased concentration of chrome in the Earth crust. Substances, polluting the environment of this region have substantial impact on condition of children's health, living at this territory, which is represented in growth of disease incidence and mortality.

\section{References}

A.M.Nagimova, (Social analysis of quality of population's life: regional aspect, Kazan State University, 2010).

Z.Z.Biktimirova,- 2005. - № 2.) Life quality: problems of measurement and assessment // Economics of region. - 2005. - No.2.

A.N.Bulatov, (Assessment of economic efficiency of corporate management at industrial companies: Candidate of economic sciences. Kazan, 2001).

A.Z.Gilmanov, (System of local self-governing bodies as factor of improving of population's life quality // Scientific work of the Perspective Economical Researches Center. Kazan: Center for innovative technology, 2010).

N.A.Gorelov, (Revenue Policy and population's life quality. St. Petersburg: St. Petersburg, 2003).

V.P.Goryainov, (Problem-structured method of analysis of public opinion monitoring // Social.- 2002. - No.4.) (State regulation of social sphere)/ O.N.Viktorov, V.L.Kurakov, N.V.Bondarenko etc. M.: Helios APB, 2000.

A.A.Davydov, A.N.Churakov, (Systematic approach to analysis of data of public opinion monitoring // Social- 2002. - No.7).

I.F.Devyatko, (Methods of social research. M.:University -book house, 2002).

V.M.Zherebin, A.N.Romanov, (Population's life level. M.:UNITY-DANA, 2002).

O.A.Kovyneva, B.I.Gerasimov, Management over the population's life quality. Tambov: Publishing firm of Tambov State Technical University, 2006).

V.K.Levashov, Stable society development: paradigms, models, strategy. M.: Academia, 2001).

I,Matveyeva, K.Mikhailova, Quality of life- the new civilizational paradigm // Standards and quality.- 2000.-No.5).

Materials of web-site of Scientific Research Laboratory on problems of life quality // Russkiy Pereplet- web portal, 1999. URL: http:// www.bel.edu.ru/lab. (appeal date- August 10, 2009).

Complex examination and assessment of condition of the environment pollution of Aktobe city. Report on Research Work of the Oil and Gas Institute named after Ye.K.Fedorov. M., 1989- p.211). Chrome pathology // Reports on Research Work of the Aktobe State Medical Institute, 2002 -2003).

G.I.Sidorenko, Ye.A.Mozhayev, Sanitary condition of the environment and health of population. M. 1987.- p.123).

B.A.Nemenko, U.I.Kenesariyev, Methodic on assessment of unfavorable factors impact of various nature on condition of children's health.// Methodical recommendations, A., 1996- p.27).

T.K.Karimov, Zh.A.Moldashev, B.V.Zasorin, M.A.Zhumangarin, Hygiene and sanitary., 1991. - No.11. - cтp.62-64 (On regional features of environment factors impact on population's health // Hygiene and sanitary, 1991. - No.11. - p.62-64).

M.G.Shandala,Ya.I.Zvinyatskovskiy, Environment and population's health, Kiev, 1988. - p.269).

P.F.Kiku, M.V.Yarygina, V.D.Bogdanova, Ya.S.Zavyalova, Ecology-Social factors and health of human. Health. Medical ecology. Science 1 (55)- 2014).

V.M.Boev, V.M.Boev, B.L.Kolesnikov, A.K.Yekimov // Hygiene and sanitary, 2008. No.3. p. 92-94.(Assessment of demographical and social-economic indicators in social-hygienic monitoring system / Hygiene and sanitary, 2008. No.3 p.92-94).

N.A.Borisov, Problems of interaction and work coordination on performance of social and hygienic monitoring/ Health protection of Russian Federation 2004. No.3. P.11-12).

B.T.Velichkovskiy, Reforms and health of country population (Ways of negative consequences negotiation) M.:Mysl, 2002- p.156).

B.T.Velichkovskiy, Social stress, labor motivation and health// Russia medical journal. 2006. No.6. p.8-14.).

A.A.Galkin, Hygiene and sanitary. 2012. No.6. стр. 27-29. (Systematization and norming of environment factors on the basis of general graphical models/ A.A.Galkin // Hygiene and Sanitary. 2012. No.6. p. 27-29).

Yu.P.Gichev, Biological aspects of ecology conditionality of early population aging (population progeria) and decrease of lifetime of Russia population /Yu.P.Gichev // Ecology of human. 2004. No.6. p.30-34).

Yu.D.Gubernskiy, Hygiene and sanitary. 2001. No.4. стр. 21-25. (Hygienic characteristics of chemical factors of risk under conditions of living environment /Hygiene and Sanitary, 2001. No.4. p. 21-25).

Yu.D.Gubernskiy, Social-hygienic monitoring of the environment/Hygiene and sanitary. 2004. No.5. p.15-17).

A.V.Datii, A.V.Datii, S.B.Selivanov, N.V.Panfilov// Hygiene and sanitary. 2004. No.5. p. 23-24. Social-hygienic monitoring and radiation hazard /Health. Medical Ecology. Science. 2013. No.2-3. P. 38-41).

Regional features of organization of social-hygienic monitoring system) / O.G.Zaprudnova // Hygiene and sanitary. 2007. No.1. p.74-76. 
Risk factors and frequency of disease incidence of children, living at the territory of technogenic pollution) / O.Ye.Konovalov, O.V.Moiseyuk, V.G.Artemov //Health protection of the Russian Federation. 2000. No.3. p. 23-24. (Health Protection of Russian Federation).

Conference of the UNO on environment and development): (informational survey) / under the editorship of V.A.Kontyug. Novosibirsk: CO $\mathrm{PAH}$, 1992. p. 4-25

M.A.Kreimer, Economic and mathematical aspects of monitoring of population health and live environment) / M.A.Kreimer // Hygiene and sanitary. 2005. No.2. p.72-75.

Medical and social monitoring) / Yu.P.Lisitsyn // Мед. газета. 2004. №.6. p.4.

Methodological aspects of assessment of organism's adaptation reaction on influence of environment's risk factors) / N.A.Meshkov // Hygiene and sanitary, 2012. No.6. p.17-21

Hygienic risk assessment for children's health in a system-living environment- population health) / M.G.Mizina, P.A.Veinikh // 3HиCO. 2008. No.10. p.37-39;

Expertize of value of indicators used during assessment of public health status)/ O.P.Lomov, V.M.Kudryavtsev // Hygiene and sanitary, 2009. No.1. p. 67-69.

Contemporary trends of disease incidence of population and leading social-hygienic factors, promoting its development) $/$ Ye.I.Nesterenko, N.V.Polunina, S.A.Oprischenko // Diseases prevention and health improvement) 2002. No.5. p.4-7. Mind-body problems in a hospital of internal diseases) / N.R.Paleyev. // Вестник Российской АМH. 1998. No.7. p.29-37.

A.I.Potapov, (Hygienic problems of population health) / A.I.Potapov, R.S.Gildenskiold, I.L.Vinokur // Health protection of the Russian Federation. 2008. No.2. p.3-4.

Yu.A.Rakhmanin, (Contemporary problems of human ecology and hygiene of environment in provision of sanitary and epidemiological well-being of population of the Russia) / Yu.A.Rakhmanin //Health protection of the Russian Federation. 2008. No.1. p.12-13.

Yu.A.Rakhmanin, O.D.Doronina, (Strategic approaches of management over the risks for reduction of human sensitivity as a result of water factor change) / Hygiene and sanitary. 2010. No.2. P.8-13.

V.R.Rembovskiy, (Medical and hygienic aspects of assessment of population health) / V.R.Rembovskiy, L.A.Mogilenkova // Hygiene and sanitary. 2008. No.2. P.46-50.

A.V.Reshetnikov, (Medical and social monitoring): Editorship. M.: Medicine, 2003. - p.10-48

L.V.Rugol (Medical and demographical aspects of health protection reforming) / L.V.Rugol // Health protection of the Russian Federation. 2010. No.6. - p.7-11.

V.G.Semenova, (Loss of population's health depending on type of location) / V.G.Semenova, N.E.Vdokushina // Health protection of the Russian Federation. 2012. No.5. - p.11-16

I.V.Semushina, (Impact of environment factors on health of region's children) / I.V.Semushina, V.V.Zhukova, A.V.Zheglova, L.V.Barkova // Health Protection of the Russian Federation. 2011. No.5. - p.27.

O.S.Kostkina, (Informational support system of making decisions during monitoring of people's health status) Tver, 2007. - p.19

Ye.D.Savilov, S.A.Vyborova, (Adaptation status as health indicator) // Hygiene and sanitary .2006. No.3 . - p.7-8 .

N.Yu.Kelina, N.V.Bezruchko. (Biochemical direction of risk factors assessment for the human's health) // Human Ecology: (conception of risk factors, ecology safety and risk management): сб . ст . (International science practical conference) / Penza: РИО ПГСХА, 2010. p.5-8

N.Yu.Kelina and others. ELPIT 2009 (IV International science and technical conference). Tolyatti: ТГУ, 2009 . T . 1.- p.264-271. (Biochemical model of analysis of population health on the basis of assessment of ecology risk factors // Ecology and safety of the life activity of industrial-transportation complexes)

N.Yu.Kelina, N.V.Bezruchko, G.K.Rubtsov, S.N.Chichkin. 2010 . publication- 3 . -p.156-161. (Assessment of impact of chemical pollution of the environment as a risk factor for a human's health (analytic survey)).

G.G.Onischenko, S.M.Novikov, Yu.A.Rakhmanin and others. (Basis of the risk assessment for population health during impact of chemical substances, polluting the environment) / Under the editorship of Yu.A.Rakhmanin, G.G.Onischenko. М.: НИИ ЭЧ и ГОС, 2002.-p.408 56. R.S.Mogilevskiy,. (Problems of life quality of a big city) L.: 1987. - p.143

Ye.V.Davydova, A.A.Davydov, (Measurement of life quality) M.,1993. - p.52

L.I.Elpiner, (Science foundation of methodology of complex forecasting of global hydro-climatic changes on Medical-ecology situation) / L.I.Elpiner// Hygiene and sanitary, 2009. No.5. p.71-76.

M.V.Yarygina, P.F.Kiku, T.V.Gorborukova, V.Yu.Ananyev. (Social and ecological assessment of environment impact on health of population of various bio-climatic zones (in terms of Primorsk Territory). Human Ecology. 2007; 7: 48-52.

M.A.Nugayev,.(Theorethical and methodological foundations of research quality of social region's potential) Kazan: publishing office of Kazan University, 2006.

M.A.Nugayev, R.M.Nugayev. Problem of correspondence of notions way of life and life quality in social research // Scientific work of Social-economical and legal sciences Institution of Academy of Sciences of the Tatarstan. Kazan: FEN, 2003.

G.P.Petropavlova, Control over quality of life of region population. Rostov-on-Don.: publishing office of Rostov University, 2003. Incomes and population life quality policy / under the editorship of P.A.Gorelov. St. Petersburg: Saint Petersburg, 2003

A.I.Subbeto Life quality control and humankind survival // Standards and quality. -1994 . - No.1.

V.O.Flek, N.A.Kravchenko, N.F.Sokovikova. Contemporary approaches to effectiveness assessment of resourse using within health protection system // Health protection manager. - 2005. - No.9.

O.F.Chistik, Indicators of social and economic region development // Statistic issues. - 2000. - No.3. 
I.A.Amanzhol, Z.A.Dikhanova, N.T.Zhaketayeva, G.A.Berdesheva, S.Sh.Atshabarova. Labor conditions and health status of employees, working in various spheres of ore mining// Medicine and Ecology. -2007. -No.3.-P.6-8.

Ye.M.Musin, T.A.Tatkeyev, R.A.Ybrayev, Ye.Zh.Otarov, G.A.Berdesheva, Akustikalyk zhane mehanikalyk tolkyndardy gigienalyk bakylau adistemesi zhaily/l Actual issues on health protection of working population: National Center of Labor Hygiene and professional diseases - Karagandy, 2008. - p.101-103

G.A.Berdesheva, Arturli kasibi- onerkasiptik toptar zhymysshylarynyn enbek uderisterinin salystyrmaly gigienalyk sipattamasy // National Center of Labor Hygiene and professional diseases. - Karagandy, 2008. - p.52 - 55

I.A.Amanzhol, G.A.Berdesheva, Z.A.Dikhanova Zher asty zhane zher usti mamandyktaryndagy zhumysshylar organizmindegi zhurektamyr zhuiesi korsetkishterinin ozgeruin fiziologiyalyk bagalau/l Theses of report of international research and practice conference- Contemporary problems of ecology physiology - Almaty, 2008 - p.14

M.N.Sadykov, Ye.Zh.Otarov, T.A.Tatkeyev, G.A.Berdesheva, Ye.M.Musin, Syrtky orta faktorlarynyn enbek zhagdaiyndagy kasibi kauiptiligin bagalaudagy mani// Theses of report of international research and practice conference- Contemporary problems of ecology physiology - Almaty, 2008 - p.137

Ye.Zh.Otarov, G.A.Berdesheva, T.A.Tatkeyev etc.. Akustikalyk tolkyndardyn zhumyshylardyn estu kabiletine aseri zhaily // Theses of report of international research and practice conference- Contemporary problems of ecology physiology- Almaty, 2008 - p.125

Ye.Zh.Otarov, Ye.M.Musin, T.A.Tatkeyev, G.A.Berdesheva etc.. Kasibi aurushandygy bar zhumysshylar tobyn reabilitatsiyalau// Theses of report of international research and practice conference- Contemporary problems of ecology physiology - Almaty, 2008 - p.126

T.A.Tatkeyev, S.A.Ibrayev, Ye.Zh.Otarov, G.A.Berdesheva, T.K.Kamashev etc.. Akustikalyk zhane mehanikalyk tolkyndardyn aserin bagalaityn fiziologiyalyk adister//Information sheet. - УГТАО Karagandy ф., 2009.

Ye.Zh.Otarov, S.A.Ibrayev, T.A.Tatkeyev, G.A.Berdesheva, T.K.Kamashev, Zhumyskerlerdin enbek zhagdaiyn zhuieli bagalau zhane sauyktyru sharalaryn azirleu//Information sheet. - УГТАО Karagandy ф.., 2009.

S.A.Ibrayev, T.A.Tatkeyev, Ye.Zh.Otarov, G.A.Berdesheva, T.K.Kamashev etc.. Ondiristin ar turli salalaryndagy kasibi kauiptilikti bagalau adistemesi//Information sheet. - УГТАО Karagandy ф.., 2009.

G.A.Berdesheva, Atkaratyn enbek operatsiyalarynyn erekshelikterine bailanysty zhumysshylardyn enbek zhagdaiyn gigienalyk bagalau/l Labor hygiene and Medical ecology. - 2009. - No.1 (22) - p.26-34

I.A.Amanzholov, Ye.A.Zhamanov, T.K.Kamashev, G.A.Berdesheva, L.S.Batyrbekova, D.K.Nazar, S.M.Atshabarov. (Research of unfavorable physical and chemical factors harmful for the health with assessment of professional risks// Theses of Republican research and practice conference- Activity of sanitary-epidemiological service and contemporary problems on population's health protection) - Karagandy, 2009. - p.15

I.A.Amanzholov, G.A.Berdesheva, T.K.Kamashev, S.T.Mendibai, Ye.A.Zhamanov. Ondiristik faktorlardyn kasibi kauip dengeine aserin gigienalyk bagalau // Health and disease. - 2010. - No.1 (80) - p.25 - 31

G.A.Berdesheva, (Hygienic assessment of professional risks having impact on health status of employees of various professionalproduction teams), Karagandy,2010.-p.7-79. 